九州大学学術情報リポジトリ

Kyushu University Institutional Repository

\title{
On some rare xanthid crabs from the Ryukyu Islands, with description of a new species
}

Miyake, Sadayoshi

Zoological Laboratory, Department of Agriculture, Kyushu University

Takeda, Masatsune

Zoological Laboratory, Department of Agriculture, Kyushu University

https://doi.org/10.5109/22762

出版情報：九州大学大学院農学研究院紀要. 14 (2)，pp.293-302，1967-03. Kyushu University バージョン：

権利関係 : 
Journal of the Faculty of Agriculture, Kyushu University, Vol. 14, No. 2 March 30, 1967

On some rare xanthid crabs from the Ryukyu Islands, with description of a new species*

Sadayoshi Miyake and Masatsune Takeda

Some interesting species of xanthid crabs from the Ryukyu Islands are deposited in the Zoological Laboratory, Kyushu University. This report is concerned with those eight species, which are referable to seven genera of the family Xanthidae. One of those species, Chlorodiella ohshimai sp. nov., was described as new to science, and some others were newly added to the fauna of Japan and its adjacent waters. In the course of a study the first malc pleopods, if necessary, were represented for the purpose of getting complete knowledge of each species. More detailed investigations of the fauna, however, would be desirable.

We are greatly indebted to the following gentlemen for providing us many valuable material upon which this study is mainly based: Dr. T. A. Uchida and Mr. H. Minei of our laboratory, Mr. K. Honda of the Akakina middle school, Amami-Oshima Island, Dr. S. Shiraishi of the Faculty of Medecine, Kurume University and Dr. Y. Ono of the Faculty of Science, Kyushu University, and we are especially indebted to Emeritus Prof. Hiroshi Ohshima of the Kyushu University for his kind guidance.

\section{Lioxanthodes alcocki Calman, 1909}

Lioxanthodes alcocki Calman, 1909, p.707, Pl.72, Figs.1-3; Guinot, 1962b, p. 8, Fig. 6a-b.

Paraxanthias alcocki: Balss, 1938, p. 50.

Description: Carapace oval and strongly convex fore and aft; the surface polished and ill-defined except for a shallow median fullow and a pair of the crescent depressions parallel to the supra-orbital borders. The front almost straight with a shallow median sinus and without

* Contributions from the Zoological Laboratory, Faculty of Agriculture, Kyushu University. No. 359. 
the lateral lobules separated from the inner supra-orbital angle by the shallow incision. The antero-lateral border thick and arched with scarce traces of the three lobes. The inner angle of the basal antennal segment just touched with the ventral prolongation of the front, while its outer angle just parallel to the inner infra-orbital angle.

Chelipeds massive, quite unequal in both sexes; palm of the larger cheliped rough with the granules arranged somewhat in rows on the outer surface, and the palm of the smaller one slender and also rough, but not so strong as in the large one. Both the movable and the immovable fingers of the larger cheliped toothed along the cutting edges bearing a good deal of hairs on the inner proximal parts, their tips not excavated, while those of the smaller one provided with sparse hairs along the prehensile edges, their tips excavated and denticulate.

Habitat: Some were taken from the living coral, Pocillopora sp., with Maldivia triunguiculata (Borradaile) and others from reef flat with Actaea polyacantha (Heller).

Material examined:

Sani, Amami-Oshima I., 1 ô, 4 ovig. 우우, 2 우 우, Zoological Laboratory, Kyushu University (ZLKU), No. 11450, Aug. 14-15, 1966, K. Honda and M. Takeda leg.

Measurements (in $\mathrm{mm}$ ):

\begin{tabular}{lccccccc}
\hline & 3 & ovig. 우 & 우 & 우 & ovig. 우 & ovig. 우 & ovig. 우 \\
\hline $\mathrm{Cb} *$ & 3.4 & 3.9 & 4.3 & 4.7 & 5.6 & 5.7 & 6.1 \\
$\mathrm{Cl}$ & 2.0 & 2.2 & 2.4 & 2.6 & 3.0 & 3.0 & 3.1 \\
$\mathrm{Cb} / \mathrm{Cl}$ & 1.7 & 1.77 & 1.79 & 1.81 & 1.87 & 1.9 & 1.97 \\
\hline
\end{tabular}

* $\mathrm{Cb}$ and $\mathrm{Cl}$ mean breadth and length of the carapace respectively.

$\mathrm{Cb} / \mathrm{Cl}$ means the ratio of breadth to length of the carapace.

Remarks: The carapace is changeable in the ratio of breadth to length of the carapace by its development, shown in measurements. In the larger material the carapace seems to be more wider than in the smaller material.

Distribution: Christmas I. (Indian Oc.); Gilbert Is.; Amami-Oshima I.

Leptodius leptodon Forest et Guinot, 1961

Leptodius leptodon Forest et Guinot, 1961, p. 65, Figs. 55, 56, 59a-b, Pl. 2, Fig. 3.

Material examined:

Shika, Ishigaki-jima I., $1 \hat{\jmath}$, ZLKU, No. 2813, Sept. 13, 1938, M. Masaki leg.; $3 \hat{\jmath} \hat{\jmath}, 2$ ९ , ZLKU, No. 835, May 19-31, 1940, S. Miyake and 
T. Kawahara leg.

Haemisaki, Iriomote-jima I., $2 \hat{\jmath} \hat{o}$ infested by Saccurina sp., ZLKU, No. 10030, Aug. 17, 1962, Y. Ono leg.

Zamami-jima I., near Okinawa-jima I., $2 \hat{\jmath} \widehat{\jmath}, 1$ 우, ZLKU, No. 11408, Jul.

24, 1964, S. Shiraishi leg.

Habitat: This species rather commonly found under the stones at the intertidal zone of the southern distrincts of the Ryukyu Islands.

Remarks: These material are closely related to the description of the carapace given by Forest and Guinot (1961), as the carapace is well sculptured, and its frontal and antero-lateral borders are somewhat convex. The present material, however, show the four antero-lateral teeth not so depressed as in $\mathbf{L}$. gracilis but more sharp. Consequently the carapace of this species closely related to $L$. exaratus rather than to $L$. gracilis.

The first male pleopod is characteristic and almost agreeable with the figures represented by Forest and Guinot (loc. cit., fig. 59).

Distribution: Tuamotu Is.; Tahiti I.; Ishigaki-jima I., Iriomote-jima I. and Zamami-jima I., Ryukyu Is.

\section{Chlorodiella ohshimai sp. nov.}

(Figs. 1, a-c, and 2, a-d)

Diagnosis: Fronto-orbital breadth more than two-thirds of the carapace. Antero-lateral border arched with a broad lobe, a sharp spine and a small tooth. Merus of the cheliped stands out more than two-thirds from the carapace, bearing an obtuse tooth on the proximal part of the upper border. Legs armed with a row of spines on the upper border of each segment.

Description of holotype: Carapace wide, gently convex in both dircctions, glabrous and ill-defined. The fronto-orbital breadth occupies more than two-thirds of the carapace. The front doubly rimmed with a small sinus, and with less prominent lateral lobules distinctly separated from the supra-orbital border.

The antero-lateral border shows a broad, rounded lobe, of which the anterior part separated from the external orbital angle by a shallow bight, and the posterior margin granulated somewhat at the lower level. Following this lobe the antero-lateral border ends in a large, sharp tooth and a minute one; the anterior sharp spine curved forwards and the posterior tooth less prominent. The postero-lateral border gently convergent, and the posterior border slightly concave in the middle.

The infra-orbital border bears one distinct notch near the external orbital angle. The hiatus between the inner angles of both the supra- 
and infra-orbital borders rather broadly opened. The basal antennal segment thickly fills the orbital hiatus, its inner angle broadly touched with the prolongation of the front, while its outer angle fails to reach to the level of the inner infra-orbital angle.

In the merus of the third maxilliped the antero-outer angle produced in some extent and the antero-inner angle not so strongly concave but truncate.

Cheliped in the right side slender. Merus granulated, standing out more than two-thirds from the carapace; the upper border bears the obtuse tooth on the proximal part. Carpus bears one prominent obtuse protuberance at the inner angle. Palm and fingers very smooth without any traces of the tubercles or granules; fingers hollow in hoofform at the tips. Cheliped in the left side missing.

Ambulatory legs slender and sparsely covered with long hairs; the upper border of each segment armed with a row of spines. Dactylus strongly biunguiculate. The male abdomen fused in the 3-5 segments. The first male pleopod as represented in Fig. 2a-d, bearing numbers of stout, somewhat wavy setae on its subterminal part.

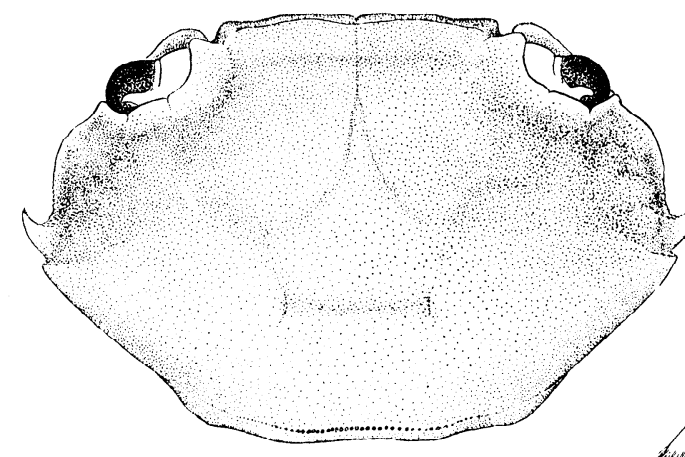

2

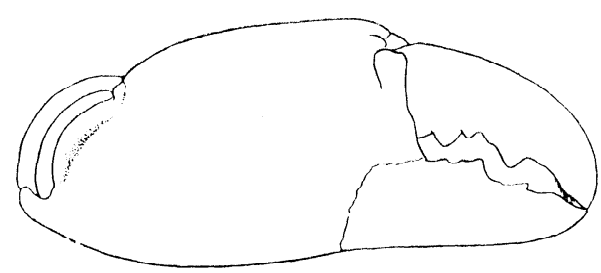

C

Fig. 1. Chlorodiella ohshimai sp. nov.

a, Carapace, $\times 5.6$; b, third maxilliped, $\times 16.8$. c, right chela, $\times 5.6$;

Type: Holotype, male, ZLKU, No. 2613, Shika, Ishigaki-jima I., Yaé- 
yama Group, Ryukyu Is., Jul. 27, 1933, H. Ohshima, H. Ikeda and S. Miyake leg.

Measurements (in $\mathrm{mm}$ ):

Breadth of carapace including lateral spines 12.5

Length of carapace
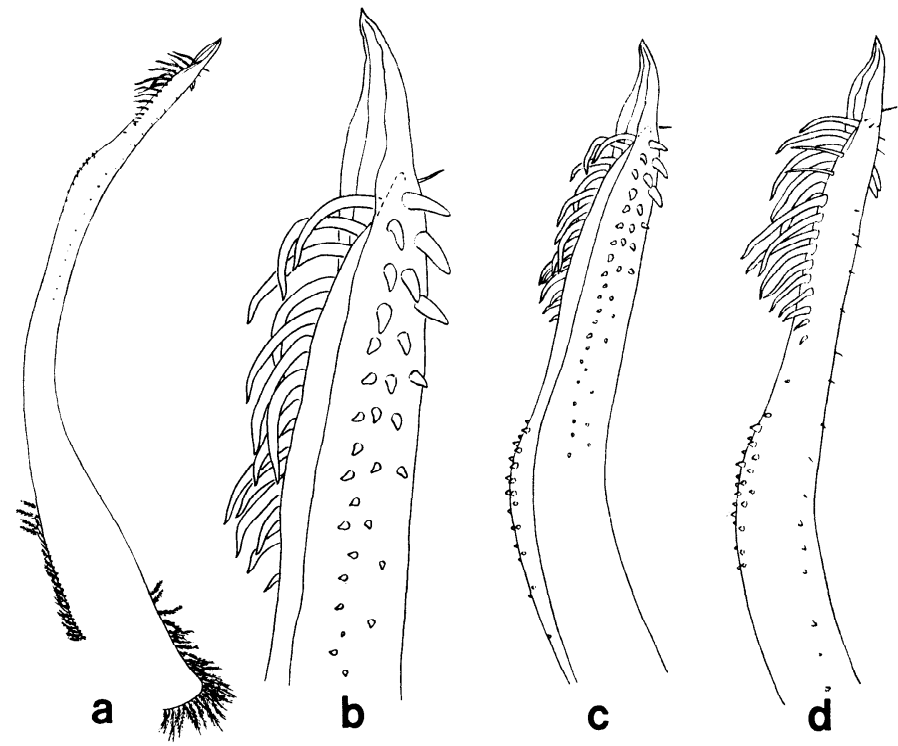

Fig. 2. First male pleopod of Chlorodiella ohshimai sp. nov. a, $\times 20$; b. $100 \times$; c, $\times 50 ; \mathrm{d}, \times 50$.

Remarks: This species is allied to Ch. nigra in such characters that the charapace is available within the size of $C h$. nigra, developing more larger than Ch. cytherea, and the merus of the cheliped bears the protuberance on the upper border. This species seems to be related to $C h$. cytherea for the fact that the last tooth of the antero-lateral border is not so distinct as that in Ch. nigra.

This species is, however, easily distinguished by the armature of the antero-lateral border of the carapace and the ornamentation of the first male pleopod.

\section{Dacryopilumnus eremita Nobili, 1906}

(Fig. 3, a c)

Dacryopilumnus eremita Nobili, 1906, p. 264 ; Edmondson, 1925, p. 42 ;

Sakai, 1939, p. 524, text-fig. 40.

Material examined:

Sani, Amami-Oshima I., 2令, ZLKU, No. 11297, Jul. 21, 1966; 3ㅅํ오. 
1 ovig. 우, 1 우, ZLKU, No. 11300, Aug. 18, 1966, K. Honda and M.

Takeda leg.

Measurements (in $\mathrm{mm}$ ):

The largest ovigerous female.

Breadth of carapace 5.8

Length of carapace ......................... 3.9

Distribution: Tuamotu Is.; Wake I.; Northern Daito-jima I. ; AmamiOshima I.

Dacryopilumnus rathbunae Balss, 1932

(Fig. 3, d-f)

Dacryopilumnus eremita: Rathbun, 1911, p. 228, P1. 16, Figs, 6, 7.

Dacryopilumnus rathbunae: Sakai, 1939, p. 525, P1. 99, Fig. 2.

Material examined:

Sani, Amami-Oshima I., 2 호옹, 1 ovig. 우, 2 우 우, ZLKU, No. 11304, Jul. 21, 1966, K. Honda and M. Takeda leg.

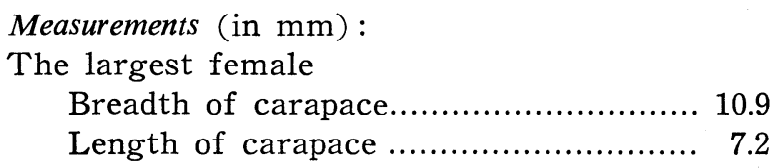

Habitat: This species as well as the preceding species is found in the hole bored on the rock at the intertidal zone of the coral reef. Their living hole is rather shallow and its opening is circular and able to be closed by the front and the chelipeds as the operculum.

Remarks: The first male pleopods of $D$. eremita and $D$. rathbunae are similar one another. In $D$. eremita the long stout setae more numerous on the middle part than in $D$. rathbunae. The second pleopods are whiplike as that in the subfamily Menippinae. In $D$. eremita this whip of the second pleopod bears two rather long plumose hairs, while in $D$. rathbunae it is coiled differently in natural state.

Distribution: Amboina Is.; Peros, Coin; Christmas I. (Indian Oc.); Northern Daitojima I.; Okinawa-jima I.; Amami-Oshima I.

\section{Epixanthus dentatus (White, 1847)}

(Fig. 3, g-i)

Epixanthus dentatus: Alcock, 1898, p. 185; Balss, 1922, p. 133.

Description: Carapace wide, finely tomentose, flattish except for the front, and the antero- and postero-lateral borders; the surface bears some 
ridges, of which the lower one is prominent and comes from the fourth antero-lateral tooth. The front straight with four lobules. The supraorbital border raised in the inner two-thirds, bearing one indistinct notch near the external angle.

The antero-lateral border thin with distinct five teeth excluding the

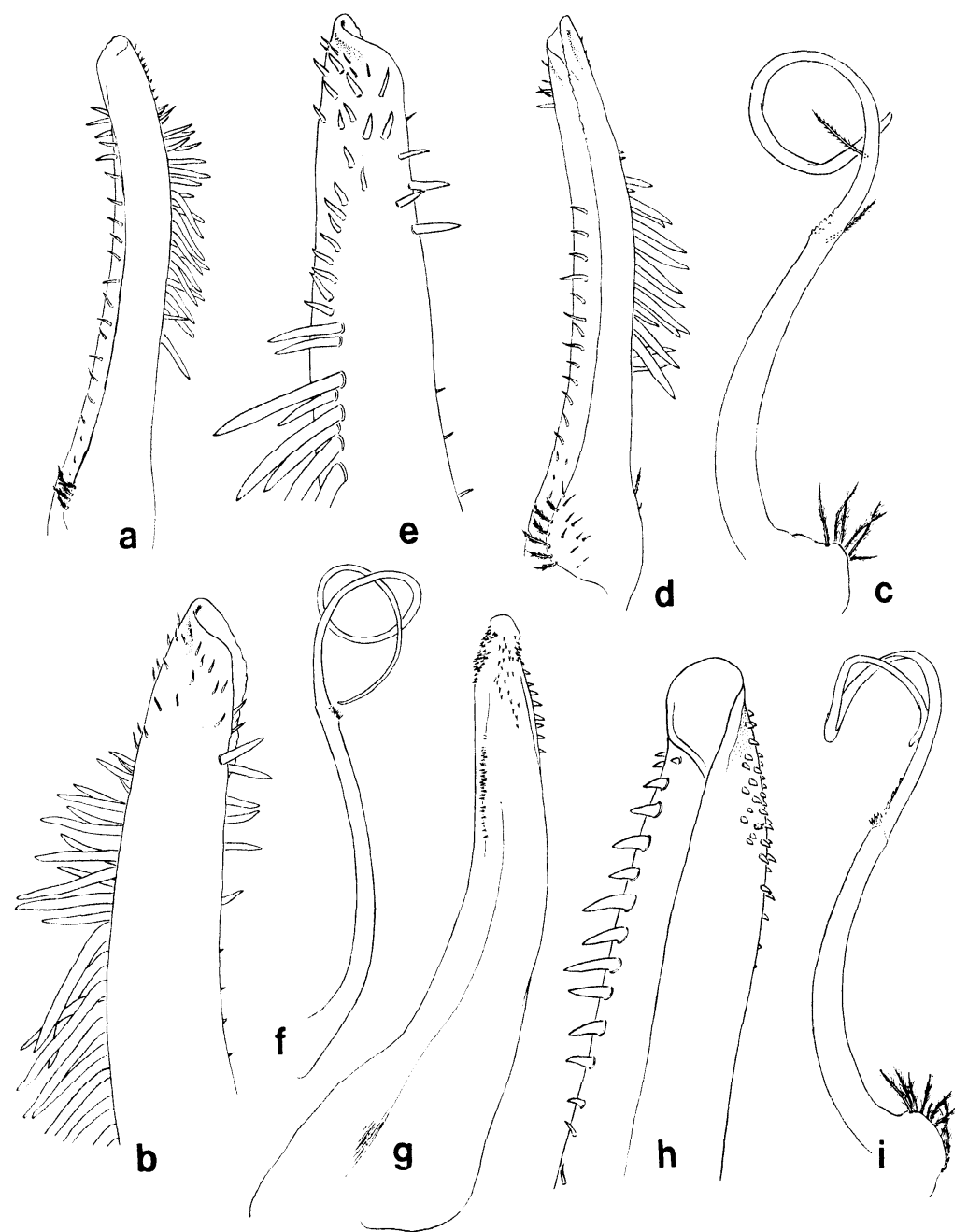

Fig. 3. Dacryopilumnus eremita Nobili ; a, first male pleopod, $\times 40$; b, same, $\times 80$; c, second male pleopod, $\times 48$.

Dacryopilumnus rathbunae Balss; d, first male pleopod, $\times 33$; e, same, $\times 80$; $\mathrm{f}$, second male pleopod, $\times 33$.

Epixanthus dentatus (White) ; g, first male pleopod, $\times 12$; h, same, $\times 33$; i, second male pleopod, $\times 8$. 
external orbital angle; the first tooth separated from the external orbital angle, and the second and third teeth as well as the first tooth subequal and more or less subtruncate. The fourth and fifth teeth sharp, but the fourth more prominent than the posterior.

Chelipeds very unequal; carpus finely tomentose with an obtuse tooth at the inner angle, palm finely granulated and also tomentose. Fingers of the smaller cheliped slender and as long as, or slightly longer than palm, and their tips sharply pointed and closed.

The first and second male pleopods as represented in Fig. $3 \mathrm{~g}-\mathrm{i}$, closely related to those of the other members of Epixanthus.

Material examined:

Komi, Iriomote-jima I., 1§, ZLKU, No. 11336, Aug. 7, 1959, H. Minei leg.

Measurements (in $\mathrm{mm}$ ):

Breadth of carapace including lateral teeth ............. 37.0

Length of carapace ........................................ 22.3

Distribution: Andaman Is.; Nicobar Is.; Mergui Archipelago; Java; Fiji Is.; Port Darwin, northern Australia; Philippines; South Formosa; Iriomote-jima I.

Domecia glabra Alcock, 1899

Domecia glabra: Forest et Guinot, 1961, p. 126, Figs. 115-116, 120-122, 124 ; cf. Guinot, 1962a, pp. 239, 240, Figs. 12, 13; Guinot, 1964b, p. 269, Figs. 1, 14, 17.

Material examined:

Omonawa, Tokuno-shima I., 1\}ิ, ZLKU, No. 11317, Aug. 2, 1966.

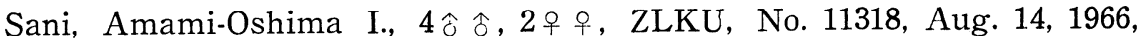
K. Honda and M. Takeda leg.

Measurements (in $\mathrm{mm}$ ):

The largest male (No. 11318)

Breadth of carapace

Length of carapace

Colour: Colour in life is whitish with the pale blue rim scattering the blackish spine along the borders of the front and the antero-lateral.

Remarks: Sometimes the species has been confused with D. hispida, from which it was well distinguished by Forest et Guinot (1961) and Guinot (1964). Differences between both species may be most emphasized by the form of the thoracic sternum. In D. hispida the thoracic sternum always slender and sharply pointed at the tip. 
Distribution: Madagascar; Réunion I.; Maldive Is.; Andaman Is.; Christmas I. (Indian Oc.) ; Viet Nam; Tuamotu Is.; Maurice I. ; Gilbert Is.; Marshall Is.; Mariana; Tokuno-shima I. and Amami-Oshima I.

\section{Maldivia triunguiculata (Borradaile, 1902)}

(Fig. 4, a-b)

Pseudozius triunguiculatus Borradaile, 1902, p. 243, Fig. 44 a-d; Rathbun, 1906, p. 861 ; cf. Balss, 1938, p. 64.

Maldivia gardineri Rathbun, 1911, p. 233, P1. 19, Figs. 5, 6.

Maldivia triunguiculata: Guinot, 1964a, p. 102, P1. 4, Figs. 1-3, P1. 12, Fig. 2.

? Jonesius minuta Sankarankutty, 1962, p. 140, Figs. 42-45.

Material examined:

Boma, Tokuno-shima I., 1 우, ZLKU, No. 11464, Jul. 29, 1966 ; Shimokushi,

Tokuno-shima I., 1 우 ZLKU, No. 11465, Jul. 30, 1966.

Sani, Amami-Oshima I., 1\}, No. 11466, Aug. 14, 1966, K. Honda and M.

Takeda leg.

Measurements (in $\mathrm{mm}$ ):

The largest male (No. 11466)

Breadth of carapace

Length of carapace

Remarks: Guinot (1964) suggested that this species may be closely allied to the species of genus Domecia. After the examination of the first male pleopod this species is proved to be so related to the species of Domecia.

In 1962 Sankarankutty recorded Jonesius minuta with the figures and description as the carapace is provided with the minute, transverse short ridges and the antcro-lateral border with two teeth. Sankarankutty's species, however, seems to be synonymous with Maldivia triunguiculata, though in the present material idenfied to $\boldsymbol{M}$. triunguiculata, the carapace is furnished with microscopical granules on the entire surface and the antero-lateral border bears three leeth, of which the third is occasionally hard to be recognized.

Distribution: Aldabra Is.; Minikoi, Mal-

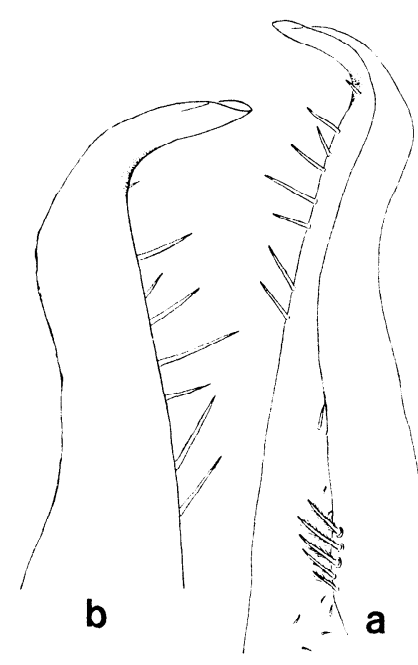

Fig. 4. First male pleopod of Maldivia triunguiculata (Borradaile)

a, $\times 80 ; \quad b, \times 120$. 
dive Is.; Solomon Is.; Hawaii; Tokuno-shima I. and Amami-Oshima I.

\section{Literature}

Alcock, A., 1898. Materials for a Carcinological Fauna of India. No. 3. Brachyura Cyclometopa. Part. 1. The family Xanthidae. J. Asiat. Soc. Bengal, 67 (2)(1) : 67233.

Balss, H., 1922. Ostasiatische Dekapoden. IV. Die Brachyrhynchen (Cancridea). Arch. Naturg., Ser. A, 88 (11): 94-166, pls. 1-2.

1938. Die Dekapoda Brachyura von Dr. Sixten Bocks Pazifik-Expedition 1917-18. Göteborgs Kungl. Vet.-och Vitterh. Samh Handl., Ser. B, 5 (7) : 1-85, pls. $1-2$.

Borradaile, L. A., 1902. Marine Crustaceans. 3. The Xanthidae and some other crabs. In: The fauna and geography of the Maldive and Laccadive Archipelagoes, 1: 237-271.

Calman, W. T., 1909. On decapod Crustacea from Christmas Island collected by Dr. C. W. Andrews. Proc. Zool. Soc. London, 1909: 703-713, pl. 72.

Edmondson, C. H., 1925. Marine zoology of tropical central Pacific. Bull. Bishop Mus., 27 : 3-62, pls. $1-4$.

Forest, J. \& D. Guinot, 1961. Crustacés Décapodes Brachyoures de Tahiti et des Tuamotu. Expédition française sur les récifs coralliens de Nouvelle-Calédonie. Volume préliminaire: i-xi, 1-195, pls. 1-18.

Guinot, D., 1962a. Sur une collection de Crustacés Décapodes Brachyoures des îles Maldives et de Mer Rouge (Expedition “Xarifa” 1957-1958). Kieler Meeresforsch., 18 (2) : 231-244, pls. $1-5$.

, 1962b. Sur quelques Crustacés Décapodes Brachyoures indo-pacifiques des collections du Musée de Munich. Opuscula Zool., 60 : 1-14.

- 1964a. sours presse. Crustacés Décapodes Brachyoures (Xanthidae) des campagnes de la Calypso en Mer Rouge (1952) dans le Golfe Persique et à l'ile Aldabra (1954). Mém. Mus. Hist. Nat. Paris, Ser. A, Zool., 32 (1) : 1-108, pls. 112.

, 1964b. Les trois espèces du genre Domecia (Decapoda, Brachyura): D. hispida Eydoux et Souleyt, D. glabra Alcock et D. acanthophora (Desconne et Schramm). Crustaceana, 7 (4) : 267-283.

Nobili, G., 1906. Diagnoses préliminaires de Crustacés Décapodes et Isopodes nouveaux recueillis par M. le Dr. G. Seurat aux íles Touamotou. Bull. Mus. Hist. Nat. Paris, 12 (5) : 256-270.

Rathbun, M. J., 1906. Brachyura and Macrura of the Hawaiian Islands. U. S. Fish Comm. Bull. for 1903, 23 (3) : 827-930, pls. 1-24.

1911. The Percy Sladen Trust expedition to the Indian Ocean in 1905. 3 (11) Marine Brachyura. Trans. Linn. Soc. London, Ser. 2, Zool., 14 (2): 191-261, pls. $15-20$.

Sakai, T., 1939. Studies on the crabs of Japan. IV. Brachygnatha, Brachyrhncha. Tokyo, 365-741, pls. 42-111.

Sankarankutty, C., 1962. On Decapoda Brachyura from the Andaman and Nicobar Islands. 2. Family Xanthidae. J. Mar. Biol. Ass. India, 4 (1) : 121-150. 